\title{
Sığacık Körfezi ve Doğanbey Burnu Deniz İçi Termal Su Kaynaklarının Deniz Suyuna Kimyasal ve Fiziksel Etkileri (Sonbahar 2016-İlkbahar 2017)
}

\author{
Chemical and Physical Effects to Seawater of Submarine \\ Thermal Springs in the Doğanbey Cape and Sığacık Gulf \\ (Autumn 2016-Spring 2017)
}

Özde Bakak ${ }^{1 *}(\mathbb{D}$, Faik Erdeniz Özel1(D)

${ }^{1}$ Dokuz Eylül Üniversitesi Deniz Bilimleri ve Teknolojsi Enstitüsü, İzmir, TÜRKIYE

Sorumlu Yazar / Corresponding Author*: ozde.badur@deu.edu.tr

Geliş Tarihi / Received: 19.02.2019

Araştırma Makalesi/Research Article Kabul Tarihi / Accepted: 10.06.2019

DOI:10.21205/deufmd.2019216327

Atıfsekli/How to cite: BAKAK O., OZEL F.E.(2019). Slğacık Körfezi ve Doğanbey Burnu Deniz İçi Termal Su Kaynaklarının Deniz Suyuna Kimyasal ve Fiziksel Etkileri (Sonbahar 2016-ilkbahar 2017), DEUFMD, 21(63), 993-1003.

\section{Öz}

Çalışmanın amacı, Karaburun Yarımadasının (Doğu Ege Denizi) güneyinde yer alan Sığacık Körfezi ve Doğanbey Burnu deniz içi hidrotermal kaynakların deniz suyuna kimyasal ve fiziksel etkilerini araştırmaktır. Kasım 2016 yılında beş istasyondan alınan yüzey ve dip su örneklerinin yerinde sıcaklık ölçümü yapılmıştır. Yüzey ve dip su sıcaklıkları; K1 $(84 \mathrm{~m}): 19,00^{\circ} \mathrm{C}-18,70^{\circ} \mathrm{C}, \mathrm{K} 2(70 \mathrm{~m})$ : $19,30^{\circ} \mathrm{C}-19,00^{\circ} \mathrm{C}, \mathrm{K} 3(63 \mathrm{~m}): 19,55^{\circ} \mathrm{C}-19,50^{\circ} \mathrm{C}, \mathrm{K} 4(43 \mathrm{~m}): 18,60^{\circ} \mathrm{C}-18,30^{\circ} \mathrm{C}$ ve $\mathrm{K} 5(95 \mathrm{~m}): 18,80^{\circ} \mathrm{C}$ $-18,40^{\circ} \mathrm{C}$ olarak ölçülmüştür. Su örneklerinin kimyasal özellikleri $\left(\mathrm{Ca}^{+2}, \mathrm{As}, \mathrm{Na}^{+2}, \mathrm{~K}^{+}, \mathrm{Li}^{+}, \mathrm{B}^{+3}, \mathrm{Mg}^{+2}\right.$, $\mathrm{Na}^{+2}, \mathrm{Cl}^{-}, \mathrm{SO}_{4}^{-2}, \mathrm{HCO}_{3}^{-}$ve $\mathrm{SiO}_{2}$ ) de analiz edilmiş olup; dip suların kimyasal özelliklerinin deniz suyu/yüzey suyu ile benzer özellikte olduğu belirlenmiștir. Bununla birlikte Nisan 2017 yılında altı istasyonda su kolonu içerisindeki sıcaklık, tuzluluk, iletkenlik ve yoğunluğun değișimi CTD cihazı ile ölçülmüştür. CTD verilerine göre dip su sıcaklığı C1 $(87 \mathrm{~m})-16,64^{\circ} \mathrm{C}, \mathrm{C} 2(21,8 \mathrm{~m})-16,79^{\circ} \mathrm{C}, \quad \mathrm{C} 3$ $(36,5 \mathrm{~m})-16,70^{\circ} \mathrm{C}, \quad \mathrm{C} 4(27,8 \mathrm{~m})-16,72^{\circ} \mathrm{C}, \mathrm{C} 5(51 \mathrm{~m})-17,16^{\circ} \mathrm{C}$ ve $\mathrm{C} 6(51 \mathrm{~m})-16,51^{\circ} \mathrm{C}$ ölçülmüştür. İstasyonlardaki sıcaklık profillerini karşılaştırdığımızda; C1 istasyonunun daha derin olmasına rağmen dip su sıcaklığının yüksek olduğu ve bunu takiben C2, C3 ve C4 istasyonlarının da C5 ve C6'ya kıyasla daha yüksek sıcaklık değerlerine sahip olduğu gözlenmiștir. Bu durum, Doğanbey Burnu yakınlarındaki istasyonlarda dip suların deniz içi hidrotermal kaynakların etkisinde olduğu şeklinde yorumlanmıștır.

Anahtar Kelimeler: Sığacık Körfezi, Doğanbey Burnu, deniz içi termal kaynaklar

\section{Abstract}

The aim of this study was to reveal the chemical and physical effects to seawater of submarine hydrothermal sources in the Sığacık Gulf and Doğanbey Cape located in Karaburun Peninsula (East Aegean Sea). In November 2016, in situ temperature measure was made both surface and deep water samples from five stations. Surface and deep water temperature values were measured as K1 (84): $19.00^{\circ} \mathrm{C}-18.70^{\circ} \mathrm{C}, \mathrm{K} 2(70 \mathrm{~m}): 19.30^{\circ} \mathrm{C}-19.00^{\circ} \mathrm{C}, \mathrm{K} 3(63 \mathrm{~m}): 19.55^{\circ} \mathrm{C}-19.50^{\circ} \mathrm{C}, \mathrm{K} 4(43 \mathrm{~m}): 18.60^{\circ} \mathrm{C}-$ $18.30^{\circ} \mathrm{C}$ ve $\mathrm{K} 5(95 \mathrm{~m}): 18.80^{\circ} \mathrm{C}-18.40^{\circ} \mathrm{C}$. The chemical properties $\left(\mathrm{Ca}^{+2}, \mathrm{As} \mathrm{Na}^{+2}, \mathrm{~K}^{+}, \mathrm{Li}^{+}, \mathrm{B}^{+3}, \mathrm{Mg}^{+2}\right.$, 
DEU FMD 21(63), 993-1003, 2019

$\mathrm{Na}^{+2}, \mathrm{Cl}^{-}, \mathrm{SO}_{4}^{-2}, \mathrm{HCO}_{3}^{-}$and $\mathrm{SiO}_{2}$ ) was analyzed and it is determined that chemical properties of deep water were similar to seawater (reference sample). However, in April 2017, the change of temperature, salinity, conductivity and density in water column at six stations was measured by CTD device. According to CTD data, temperature values were measured as $\mathrm{C} 1(87 \mathrm{~m})-16,64^{\circ} \mathrm{C}, \mathrm{C} 2(21,8 \mathrm{~m})$ $-16,79^{\circ} \mathrm{C}, \mathrm{C} 3(36,5 \mathrm{~m})-16,70^{\circ} \mathrm{C}, \mathrm{C} 4(27,8 \mathrm{~m})-16,72^{\circ} \mathrm{C}, \mathrm{C} 5(51 \mathrm{~m})-17,16^{\circ} \mathrm{C}$ and $\mathrm{C} 6(51 \mathrm{~m})-16,51^{\circ} \mathrm{C}$. When compare the temperature curves of all stations, the deep water temperature in the $\mathrm{C} 1$ station was highest although its deeper station than others, followed by the C2 and C4 stations' temperature are higher than C5 and C6. This situation is interpreted as the effect of submarine thermal springs in stations near Doğanbey Cape.

Keywords: Siğacık Gulf, Doğanbey Cape, submarine thermal springs.

\section{Giriș}

Ege Denizi Türkiye kıyı alanlarında çok sayıda sı̆ deniz içi hidrotermal kaynaklar bulunmaktadır. Kuzeyden güneye doğru bu alanlar; Gökçeada, Edremit Körfezi, Alibey ve Maden adaları, Midilli Adası, Dikili Körfezi, Aliağa - Karacaağaç Koyu ve Ilıca Burnu, Karaburun Yarımadası, Çeşme-Ilıca Koyu, Doğanbey Burnu ve Kuşadası Körfezi olarak siralananilir [1].

Belirtilen termal alanlarda yapılan çalışmalar sonucunda elde edilen bulgular ise; Gökçeada ve Edremit Körfezi (termal alanlarla ilgili foramanifer tespit edilmiștir) [2, 3], Alibey ve Maden adaları (termal kaynakla ilişkili yapılar gözlenmiştir) [4], Batı Ege Denizi Yunanistan kıyıları ve Midilli Adası (su sıcaklığı $39,7^{\circ} \mathrm{C}$, $43,5^{\circ} \mathrm{C}, 46,5^{\circ} \mathrm{C}, 46,9^{\circ} \mathrm{C}, 69^{\circ} \mathrm{C}$ arasında değișen ve tuzlu su özelliğini taşıyan çok sayıda kaplıca bulunmaktadır) [1], Dikili Körfezi (termal kaynaklarla ilişkili yapılar belirlenmiştir) [5], Aliağa - Karacaağaç Koyu kuzeybatısı $\left(40^{\circ} \mathrm{C}\right)$ ve Ilıca Burnu $\left(51^{\circ} \mathrm{C}\right)$ [6], Karaburun Yarımadası (termal kaynaklarla ilişkili yapılar belirlenmiştir) [7], Çeşme-Ilıca Koyu (kaynak sıcaklığı $28,4^{\circ} \mathrm{C}$ olarak ölçülmüş ancak $1940^{\prime}$ lı yıllarda ölçülen değer $59^{\circ} \mathrm{C}$ ] [8, 9], Doğanbey Burnu (su derinliği 0,20-31,80 m, dip su sıcaklığ 19,95 - 23,32 ${ }^{\circ} \mathrm{C}$ ) [1], Kuşadası Körfezi (su derinliği $9,2-11,3 \mathrm{~m}$, su sıcaklığ $17,5^{\circ} \mathrm{C}$ olarak belirlenmiştir) [10].

Doğanbey Burnu ile Seferihisar arasında kalan alanda da jeotermal kaynaklar mevcuttur. $\mathrm{Bu}$ alanlar kuzeyden güneye; Seferihisar $\left(140^{\circ} \mathrm{C}\right)[11,12]$, Cumalı $\left(72^{\circ} \mathrm{C}\right)$, Doğanbey Tuzlası $\left(52,5-49,5^{\circ} \mathrm{C}\right)$, Doğanbey $\left(48,5-89^{\circ} \mathrm{C}\right)$ ve Karakoç $\left(33-65^{\circ} \mathrm{C}\right)$ dır [1](Şekil 1a). Doğanbey Koyu (Kuşadası Körfezi) deniz alanında oşinografik ve güncel çökel dağılım haritaları

yapılmıştır $[13,14]$. Çalışmaya göre Doğanbey Burnu kıyı bölgesinde Doğanbey Adası etrafındaki alanda kıyıdan açığa doğru çökel tane boylarının küçüldüğü belirlenmiştir. Bölgede üç tip çökel birim mevcuttur. Bunlar kıyıdan açığa doğru sahile paralel bantlar şeklinde dağılım sunmuştur. Bölgede kıyıdan başlayarak çakılkum (-20 m'ye kadar), siltli kum (-20 m ile -100 $m$ arasında) ve kumlu silt ( -150 m'ye kadar devam etmekte) olarak sinıflandırılmıştır. Doğanbey Koyu'nda yapılan oşinografik çalışmalar sonucunda yüzey su sıcaklığının hava sıcaklığına bağlı olarak değiștiği belirtilmekte olup termoklin tabakasının $20^{\circ} \mathrm{C}^{\prime}$ den başladığ ve $15-17^{\circ} \mathrm{C}^{\prime}$ de dengelendiği gözlenmiştir. Bölgede $50 \mathrm{~m}$ derinlikte ise alt su tabakasına geçilmektedir [13]. Aynı çalışmada yüzey ve alt tabaka arasında tuzluluk farkı, kış ve ilkbahar mevsimlerinde yok denecek kadar az olduğu belirlenmiştir.

Doğanbey Burnu güney kıyılarında karadan ve denizden yapılan hidrojeolojik çalışmada, kara ile zaman zaman bağlantısı kesilen Bölme mevkiinde küçük adacığın doğu kenarında beş adet sıcak su kaynağı belirlenmiş olup bunların ikisi adacığın kara ile bağlantılı olduğu kuzey ucunda diğer üçü ise Bölme adasının kuzeydoğusunda kıyıda bulunan su yüzeyinden bulunan mağaranın içerisinden (deniz tabanından) çlktığı belirtilmiştir (Şekil 1c)[1, 15]. Sıcak suyun çıktığı mağara çevresi insanların yürüyebileceği kadar sığ bir derinliğe sahip olup mağara içerisinden gaz çıkıșları ve sıcak su akıntılarının olması sebebi ile bu bölge günüzmüde turistik cazibe merkezi haline gelmiştir. Ayrıca kaynakların dışında deniz tabanında çeşitli noktalarda da sıcak su çıkışları 
DEU FMD 21(63), 993-1003, 2019

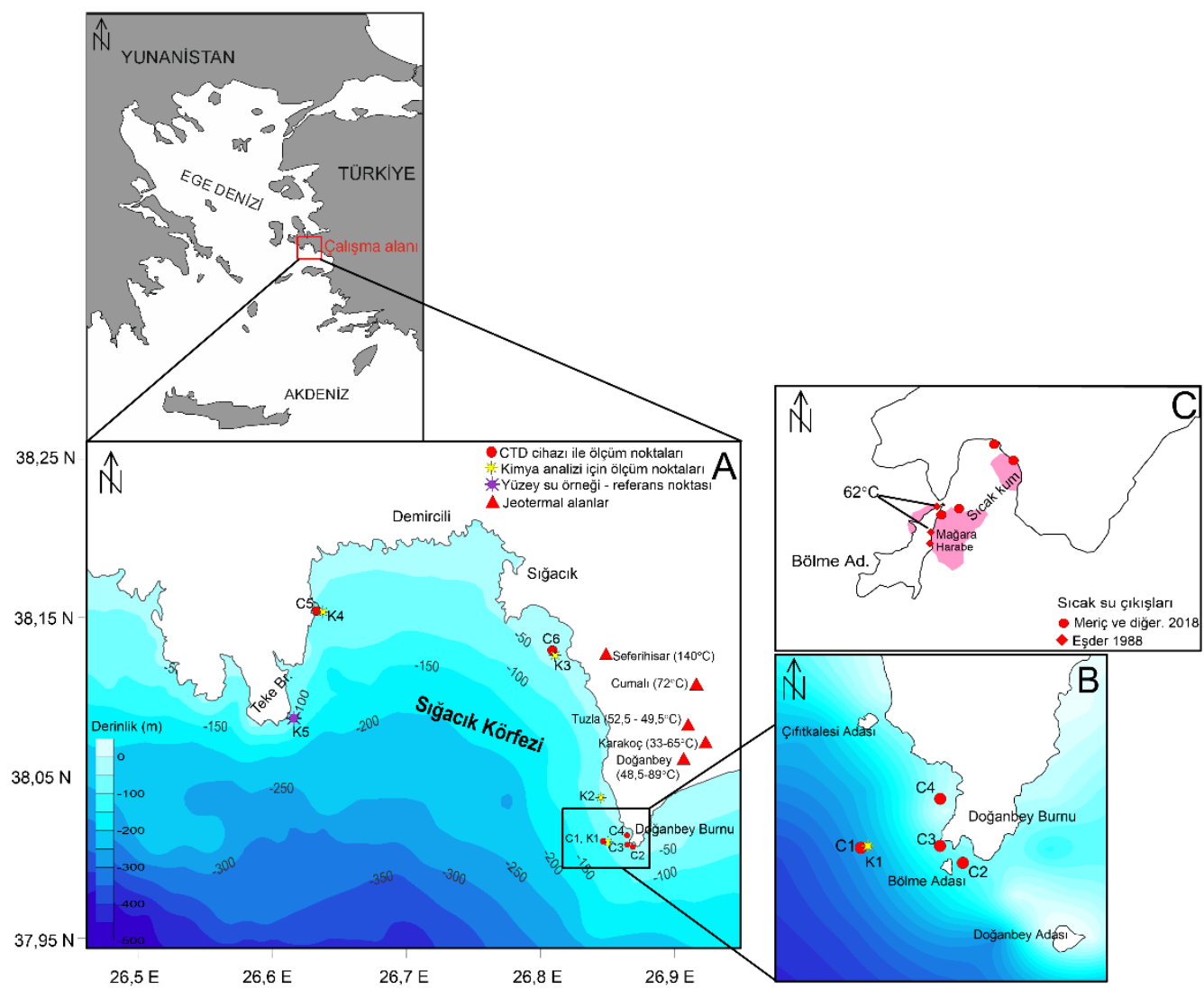

Şekil 1. a) Çalıșma alanı yer bulduru haritası ile ölçüm yapılan istasyonların konumları, bölgenin batimetrisi ve jeotermal alanlar, b) Doğanbey Burnu kıyılarındaki CTD cihazı ile yapılan ölçüm istasyonlarının yakınlaştırılmış görüntüsü ve c) bölgede daha önce yapılan çalışmalar sonucunda belirlenen sıcak noktaların konumları $[1,15]$.

gözlemlenmiş ve deniz dibindeki 15 metre derinlikte yer alan ve oldukça geniș bir alanı kaplayan kumların sıcaklıkları $62^{\circ} \mathrm{C}$ ölçülmüştür (Şekil 1c)[15]. Doğanbey Burnu'nda yapılan bir başka çalışmada karadan ve denizden su örneklerinin kimyasal analizler ile bölge hidrojeolojik açıdan incelenmiş ve yeraltı sularının kimyasal bileşiminin yerel sular ile deniz suyunun farklı oranlarda karışması ile kontrol edildiği belirlenmiştir [12]. Deniz içi hidrotermal aktivite, yüksek ısı akısına sahip alanlarda meteorik suların derinlere nüfuz etmesini sağlayan kanallar görevi gören bölgesel faylar tarafindan sinırlandırılmaktadır [16].

Doğanbey Burnu'ndaki sıcak su çıkışlarını sınırlandıran yapının ise bölgede karadan deniz tabanına kadar uzanan Tuzla fayı olduğu bilinmektedir [1]. Buna göre sıcak su çıkıșları karadaki jeotermal kaynakların uzantısı olarak deniz tabanında da etkisini devam ettirebilmektedir. Bununla birlikte Doğanbey Burnu'nda hidrotermal kaynakların mikro ve makrofauna toplulukları üzerine etkisini araştırmak için 16 Ağustos 2015'de yapılan çalışmada su derinliği 0,20 - 31,80m, dip su sicaklığı $19,95-23,32^{\circ} \mathrm{C}$ ve dip tuzluluğu \%o38,99 - 39,24 arasında değiștiği belirtilmiștir [1]. Benzer çalışma Doğanbey Koyu ve Kuşadası Körfezi'nde de mevcuttur $[17,18]$.

Yeraltında jeotermal gradyan etkisi ile ısınarak faylar boyunca yüzeye çıkan hidrotermal su geçtiği bölgelerdeki kayaçlarla etkileşimi sonucunda kimyasal içeriği değișmekte ve pek çok iz element (V, Co, Ni, Cu, Zn, As, Se, $\mathrm{Al}, \mathrm{Ag}, \mathrm{Cd}$, $\mathrm{Sb}, \mathrm{Cs}, \mathrm{Ba}, \mathrm{W}, \mathrm{Au}, \mathrm{TI}, \mathrm{Pb}$ ) zenginleșmektedir [19]. İz elementler dışında hidrotermal sularda gözlenen diğer konsantrasyonlar ise; $\mathrm{Cl}^{-}$, 
DEU FMD 21(63), 993-1003, 2019

$\mathrm{HCO}_{3}^{-}, \mathrm{SO}_{4}^{-2}, \mathrm{~F}^{-}, \mathrm{Br}^{-}, \mathrm{I}^{-}$gibi anyonlar ve $\mathrm{Na}^{+2}, \mathrm{~K}^{+}$, $\mathrm{Li}^{+}, \mathrm{Ca}^{+2}, \mathrm{Mg}^{+2}, \mathrm{Rb}^{+}, \mathrm{Cs}^{+}, \mathrm{Mn}^{+}, \mathrm{Fe}^{+}$gibi katyonlardır. Hidrotermal sular, $\mathrm{Na}^{+2}, \mathrm{~K}^{+}, \mathrm{Ca}^{+2}, \mathrm{Cl}^{-}, \mathrm{SiO}_{2}$, ve $\mathrm{H}_{2} \mathrm{~S}$ konsantrasyonu deniz suyuna göre oldukça zengin iken $\mathrm{Mg}^{+}$ve $\mathrm{SO}_{4}^{-2}$ bakımından fakirdir [20]. Bununla birlikte Arsenik elementi de sığ deniz hidrotermal çıkışlarda ağız etrafında deniz canlı yaşamını etkileyen elementlerden biri olduğu için bu alanların belirlenmesinde önemli rol oynamaktadır [21]. Ege Denizi Helenik yayı boyunca meydana gelen deniz tabanı sıcak su çıkışlarının olduğu bölgede ise $\mathrm{Ca}^{+2}$ ve $\mathrm{Li}^{+}$konsantrasyonları 235,8 - $11629 \mathrm{mg} / \mathrm{L}$ ve 7,7 - 825 mg/L ölçülmüştür [22]. Çalışmada, $\mathrm{Ca}^{+2}$ ve $\mathrm{Li}^{+}$konsantrasyonları en yüksek sırasıyla $\mathrm{K} 3$ (492 mg/L) ve K5 (deniz suyu örneği - 0,09 $\mathrm{mg} / \mathrm{L}$ ) istasyonlarında bulunmuştur.

Çalışma, Sığacık Körfezi ve Doğanbey Burnu kıyı bölgesindeki deniz suyunun Kasım 2016'da kimyasal analiz ve Nisan 2017'de fiziksel özelliklerinin ölçülmesi ve bu ölçümlerden hareketle hidrotermal kaynakların deniz suyuna etkileri incelenmeye çalışılmıştır.

\section{Materyal ve Metot}

Sığacık Körfezi ve Doğanbey Burnu kıyı bölgesinde Kasım 2016 yılında Dokuz Eylül-1 gemisi ile yapılan seferde beş istasyonda Nansen şișesi ile yüzey ve dip su örneklerinin yerinde WTW marka multimetre cihazı ile sıcaklık değerleri ölçülmüştür. Aynı anda su örnekleri kimyasal analizler için 1lt'lik plastik şeffaf bidonlara aktarılmıștır. Analiz için ayrılan örnekler gemi içerisinde ışık almayan saklama koşullarına uygun ortamda muhafaza edilmiştir. Kimyasal analiz sonuçlarının değerlendirilmesi için çalışma alanından uzakta yüzey su örneği alınmış ve yukarıda belirtilen tüm işlemler bu örnek için de uygulanmıştır.

İstasyonlar $\quad \mathrm{K} 1 \quad-\quad \mathrm{K} 5 \quad$ şeklinde numaralandırılmıștır ve Doğanbey Burnu yakınlarında K1 ve K2 örnekleme istasyonları, körfezin doğusunda karadaki fay hatının deniz tabanında da devamı olduğu düşünülen hat üzerinde K3 istasyonu, körfezin doğusunda bulunan mağara girişi yakınında K4 istasyonu ve referans olarak Teke Burnu açıklarında K5 istasyonu belirlenmiştir (Şekil $1 \mathrm{a}$ ve $1 \mathrm{~b}$ ). İstasyonların dip su derinlikleri $\mathrm{K} 1$ - 88m, K2 70m, K3 - 63m, K4 - 43m ve K5 - 95m'dir (Tablo 1).

Deniz içi hidrotermal etkilerin belirlenmesi için su örneklerindeki anyon - katyon konsantrasyon miktarlarının ölçülmesi için ICP-
MS $\left(\mathrm{Ca}^{+2}, \mathrm{As}, \mathrm{Na}^{+2}, \mathrm{~K}^{+}, \mathrm{Li}^{+}, \mathrm{B}^{+3}\right.$ ve $\left.\mathrm{SiO}_{2}\right)$, titrimetrik $\left(\mathrm{Cl}^{-}\right.$ve $\left.\mathrm{HCO}_{3}^{-}\right)$ve gravimetrik $\left(\mathrm{SO}_{4}^{-2}\right)$ yöntemler uygulanmıştır. Analizler kalite ve akreditasyon standartlarma uygun olan Dokuz Eylül Üniversitesi Çevre Mühendisliği Atıksu Laboratuarında yapılmış olup sonuçlar Tablo 1' de verilmiștir. Nisan 2017 yılında düzenlenen seferde, Sığacık Körfezi ve Doğanbey Burnu kıyı bölgesinde belirlenen altı istasyonda Valeport firmasının "MIDAS CTD Profiler" (daha önce Model 606 olarak bilinmekte) ekipmanı kullanılarak deniz yüzeyinden tabanına kadar olan su kolonu içerisindeki fiziksel parametreler (sıcaklık, tuzluluk, iletkenlik ve yoğunluk) ölçülmüştür. İstasyonlara ulaşıldığında el ile indirilerek cihaz su kolonu içerisinde ölçüm alması sağlanmıștır. CTD cihazı 1m aralıklarla ölçüm almıştır. MIDAS CTD cihazı basınç, sıcaklık ve iletkenlik değerlerini ölçmekte olup tuzluluk ve yoğunluk değerlerini hesaplamaktadır. Ölçülen ve hesaplanan tüm fiziksel parametler cihazın veri bankasında toplanmaktadır.

İstasyonlar C1 - C6 şeklinde numaralandırılmış olup konumları Şekil 1a ve 1b'de verilmiștir. C5 ve C6 istasyonları kimyasal analiz için örnekleme yapılan K3 ve K4 istasyonları ile aynıdır. C1, C2, C3 ve C4 istasyonları Doğanbey Burnu kıyı bölgesinde yer almaktadır. İstasyonların dip su derinlikleri $\mathrm{C} 1-87 \mathrm{~m}, \mathrm{C} 2-21,8 \mathrm{~m}, \mathrm{C} 3-36,5 \mathrm{~m}$, C4 - 27,8m, C5 $-51 \mathrm{~m}$ ve C6 - $51 \mathrm{~m}$ 'dir.

CTD cihazından alınan veriler GRAPHER12 yazılım programı kullanılarak;

a) herbir istasyon için ayrı ayrı tuzluluk - sıcaklık - iletkenlik - yoğunluk parametrelerini içeren grafikler (Şekil 2 ve 3) ve

b) sıcaklık - tuzluluk değişimine göre istasyonların karşılaştırıldığı grafikler (Şekil 4) hazırlanmıştır.

\section{Bulgular}

Çalışma alanının derinlik haritası Seyir Hidrografi ve Oşinografi Dairesi Başkanlığının Ege Denizi Batı Kıyıları 1/100.000 ölçekli haritasından sayısallaștırılmış olup istasyon verileri ve bölge ile ilgili tüm bilgiler harita

üzerine eklenmiştir (Şekil 1a). Sığacık Körfezi ve Doğanbey Burnu taban topografyası açıklara doğru kıyıya paralel biçimde derinleşmektedir. Batimetrik derinlik konturları -50, - 100, -150, -200 m olarak kıyıya paralel devam etmekte olup Doğanbey Burnu'nda konturlar birbirlerine iyice yaklaşmakta ve derinlikler bu bölgede ani olarak artmaktadır (Şekil 1a). Çalıșma alanı içerisinde 
DEU FMD 21(63), 993-1003, 2019

Kasım 2016 yılında seferde yerinde yapılan ölçümde elde edilen yüzey ve dip su sicaklık değerleri $\mathrm{K} 1: 19,00^{\circ} \mathrm{C}-18,70^{\circ} \mathrm{C}, \mathrm{K} 2: 19,30^{\circ} \mathrm{C}-$ $19,00^{\circ} \mathrm{C}, \mathrm{K} 3: 19,55^{\circ} \mathrm{C}-19,50^{\circ} \mathrm{C}, \mathrm{K} 4: 18,60^{\circ} \mathrm{C}-$ $18,30^{\circ} \mathrm{C}$ ve $\mathrm{K} 5$ (referans istasyonu) : $18,80^{\circ} \mathrm{C}-$ $18,40^{\circ} \mathrm{C}^{\prime}$ dir.

Çalışma alanından toplanan su örneklerinin kimyasal analiz sonuçlarına göre; K1, K2, K3 ve K4 istasyonlarındaki dip suların konsantrasyon miktarları $\mathrm{Ca}^{+}: 438-438 \mathrm{mg} / \mathrm{L}, \mathrm{Mg}^{+2}: 1424-$ $1585 \mathrm{mg} / \mathrm{L}, \mathrm{Na}^{+2}: 11360-13087 \mathrm{mg} / \mathrm{L} \mathrm{mg} / \mathrm{L}, \mathrm{K}^{+}$ : $463-536 \mathrm{mg} / \mathrm{L}^{\mathrm{Li}^{+}}: 0,06-0,1 \mathrm{mg} / \mathrm{L}$, As : $<0,01, \quad \mathrm{~B}^{+}:<0,01, \quad \mathrm{Cl}^{-}: 22493-22493 \mathrm{mg} / \mathrm{L}$, $\mathrm{SO}_{4}^{-2}: 3078-3078 \mathrm{mg} / \mathrm{L}, \mathrm{SiO}_{2}:<0,01$ ve $\mathrm{HCO}_{3}^{-}$ : 154 - $171 \mathrm{mg} / \mathrm{L}$ olarak ölçülmüștür.

Referans noktası olarak belirlenen K5 istasyonundan alınan yüzey su örneğindeki değerler ise $\mathrm{Ca}^{+2}$ (482 mg/L), $\mathrm{Mg}^{+2} \quad$ (1514 $\mathrm{mg} / \mathrm{L}), \quad \mathrm{Na}^{+2} \quad(1154 \mathrm{mg} / \mathrm{L}), \mathrm{K}^{+}(447 \mathrm{mg} / \mathrm{L}), \mathrm{Li}^{+}$ $(0,09 \mathrm{mg} / \mathrm{L})$, As $(<0,01), \mathrm{B}^{+3}(<0,01), \mathrm{Cl}^{-}(27743$ $\mathrm{mg} / \mathrm{L}), \mathrm{SO}_{4}^{-2}(3277 \mathrm{mg} / \mathrm{L}), \mathrm{SiO}_{2}(<0,01)$ ve $\mathrm{HCO}_{3}^{-}$ (173 mg/L) ölçülmüştür (Tablo 1).

Nisan 2017 yılında yapılan seferde, Sığacık Körfezi ve Doğanbey Burnu kıyı bölgesinde belirlenen 6 istasyonda CTD cihazı ile yapılan ölçümler sonucunda; yüzey suyu sıcaklıkları; C1 - $16,99^{\circ} \mathrm{C}, \mathrm{C} 2-17,14^{\circ} \mathrm{C}, \mathrm{C} 3-17,09^{\circ} \mathrm{C}, \mathrm{C} 4$ $17,55^{\circ} \mathrm{C}, \mathrm{C} 5-17,16^{\circ} \mathrm{C}$ ve $\mathrm{C} 6-17,43^{\circ} \mathrm{C}$, iletkenlik; $\mathrm{C} 1-49,91 \mathrm{mS} / \mathrm{cm}, \mathrm{C} 2-50,06 \mathrm{mS} / \mathrm{cm}, \mathrm{C} 3-50,06$ $\mathrm{mS} / \mathrm{cm}, \mathrm{C} 4-50,52 \mathrm{mS} / \mathrm{cm}, \mathrm{C} 5-50,09 \mathrm{mS} / \mathrm{cm}$ ve C6 - 50,40 mS/cm, tuzluluklarl; C1 - 39,428 ppt, C2 - 39,413 ppt, C3 - 39,415 ppt, C4 - 39,412 ppt, C5 - 39,410 ppt ve C6 - 39,437 ppt, yoğunlukları; $\mathrm{C} 1-28,92 \mathrm{gr} / \mathrm{cm}^{3}, \mathrm{C} 2-28,87 \mathrm{gr} / \mathrm{cm}^{3}, \mathrm{C} 3-28,89$ $\mathrm{gr} / \mathrm{cm}^{3}, \mathrm{C} 4-28,77 \mathrm{gr} / \mathrm{cm}^{3}, \mathrm{C} 5-28,89 \mathrm{gr} / \mathrm{cm}^{3} \mathrm{ve}$ C6 - 28,81 gr $/ \mathrm{cm}^{3}$ olarak ölçülmüștür.

Dip suların sicakları; $\mathrm{C} 1-16,64^{\circ} \mathrm{C}, \mathrm{C} 2-16,79^{\circ} \mathrm{C}$, $\mathrm{C} 3-16,70^{\circ} \mathrm{C}, \mathrm{C} 4-16,72^{\circ} \mathrm{C}, \mathrm{C} 5-16,50^{\circ} \mathrm{C}, \mathrm{C} 6-$ $16,51^{\circ} \mathrm{C}$, iletkenlikleri; $\mathrm{C} 1-49,55 \mathrm{mS} / \mathrm{cm}, \mathrm{C} 2-$ 49,68 mS/cm, C3 - 49,59 mS/cm, C4 - 49,61 $\mathrm{mS} / \mathrm{cm}, \mathrm{C} 5-49,37 \mathrm{mS} / \mathrm{cm}$ ve C6 - 49,38 mS/cm, tuzluluklarl; C1 - 39,411 ppt, C2 - 39,412 ppt, C3 - 39,411 ppt, C4 - 39,410 pt, C5 - 39,407 ppt ve C6 - 39,405 ppt, yoğunluklarl; C1 - 29,37 gr/ $/ \mathrm{cm}^{3}$, $\mathrm{C} 2$ - 29,05 gr $/ \mathrm{cm}^{3}, \mathrm{C} 3-29,13 \mathrm{gr} / \mathrm{cm}^{3}, \mathrm{C} 4-29,09$ $\mathrm{gr} / \mathrm{cm}^{3}$, C5-29,24 gr $/ \mathrm{cm}^{3}$ ve C6-29,41 $\mathrm{gr} / \mathrm{cm}^{3}$ ölçülmüștür. Sıcaklık, iletkenlik, tuzluluk ve yoğunluk parametrelerinin su kolonundaki değişim profilleri Şekil 2, 3 ve 4'te verilmiștir.

\section{Tartışma ve Sonuçlar}

Kasım 2016 (Sonbahar) yılında çalışılan 4 istasyonda sıcaklıklarda yüzeyden deniz tabanına doğru $0,05^{\circ} \mathrm{C}$ ile $0,40^{\circ} \mathrm{C}$ azalma gözlenmiştir. İstasyonlar, dip su sıcaklıklarına göre büyükten küçüğe doğru K3 > K2 > K1 > K4 şeklinde sıralanmaktadır (K5 istasyonu referans istasyonu olduğundan hidrotermal açıdan değerlendirilmemiştir). Buna göre dip su sıcaklık değerlerinin körfezin doğu kıyısında daha yüksek olduğu görülmüştür. En yüksek yüzey ve dip su sıcaklık değerine sahip olan K3 istasyonu ise Doğanbey Burnu yakınında bulunmakta olup hidrotermal kaynakların etkisinde olabileceği düşünülmüştür.

İstasyonlardaki suların kimyasal özellikleri hidrotermal bakımdan değerlendirilmesi aşamasında ise dip sularda ölçülen $\mathrm{Ca}^{+}, \mathrm{Mg}^{+2}$, $\mathrm{Na}^{+2}, \mathrm{~K}^{+}, \mathrm{Li}^{+}, \mathrm{As}, \mathrm{B}^{+}, \mathrm{Cl}^{-}, \mathrm{SO}_{4}^{-2}, \mathrm{SiO}_{2}$ ve $\mathrm{HCO}_{3}^{-}$ konsantrasyonları referans noktası olarak belirlenen $\mathrm{K} 5$ istasyonu yüzey su örneği ile karşılaştırılmıştır. Termal sular $\mathrm{HCO}_{3}^{-}, \mathrm{Ca}^{+}, \mathrm{K}^{+}$, $\mathrm{Li}^{+}$ve $\mathrm{B}^{+3}$ konsantrasyonu bakımından deniz suyuna göre zengindir [21]. Ege Denizi Helenik yayı boyunca meydana gelen deniz tabanı sıcak su çıkışlarının olduğu bölgeden alınan su örneklerinde $\mathrm{Ca}^{+2}$ ve $\mathrm{Li}^{+}$konsantrasyonları 235,8 - 11629 mg/L ve 7,7 - 825 mg/L ölçülmüștür [22]. Çalışmada, $\mathrm{Ca}^{+2}$ ve $\mathrm{Li}^{+}$konsantrasyonları en yüksek sırasıyla K3 (492 mg/L) ve K1 $(0,13$ $\mathrm{mg} / \mathrm{L}$ ) istasyonlarında bulunmuștur. Elde edilen $\mathrm{HCO}_{3}^{-}, \mathrm{Ca}^{+2}, \mathrm{~K}^{+}, \mathrm{Li}^{+}$ve $\mathrm{B}^{+3}$ konsantrasyonlar1, deniz suyuna yakın özellik sunmuş ve hidrotermal açıdan zenginleşme gözlenmemiştir. $\mathrm{Na}^{+2}, \mathrm{Cl}^{-}$ve $\mathrm{SiO}_{2}$ konsantrasyonları bakımından da hidrotermal sular deniz suyuna göre zengin iken $\mathrm{Mg}^{+}$ve $\mathrm{SO}_{4}{ }^{-2}$ bakımından fakirdir [20]. Çalışmamızda $\mathrm{Na}^{+2}$, $\mathrm{Cl}^{-}$ve $\mathrm{SiO}_{2}$ konsantrasyonları deniz suyu ile karşılaştırıldığında zenginleşme gözlenmemiş olup öte yandan tüm su örneklerinde $\mathrm{SiO}_{2}$ konsantrasyon miktarı $<0,01 \mathrm{mg} / \mathrm{L}$ olarak ölçülmüştür. Arsenik elementi bakımından incelendiğinde, özellikle sı̆̆ deniz hidrotermal çıkıșlarda ağız etrafında deniz canlı yașamını etkileyen elementlerden biri olduğu için bu alanların belirlenmesinde önemli rol oynamaktadır [21]. 
DEU FMD 21(63), 993-1003, 2019

Sığacık Körfezi

İst. C1 - CTD
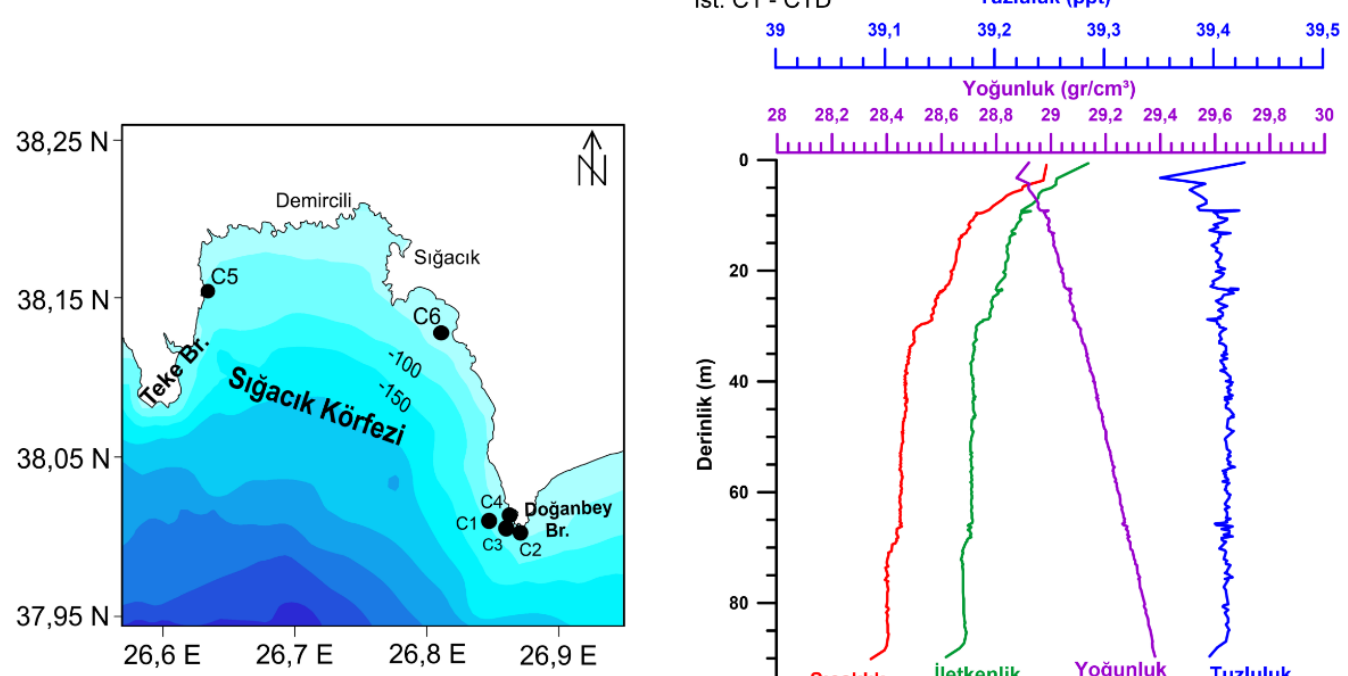

$\begin{array}{lllllllllll}28 & 28,2 & 28,4 & 28,6 & 28,8 & 29 & 29,2 & 29,4 & 29,6 & 29,8 & 30\end{array}$

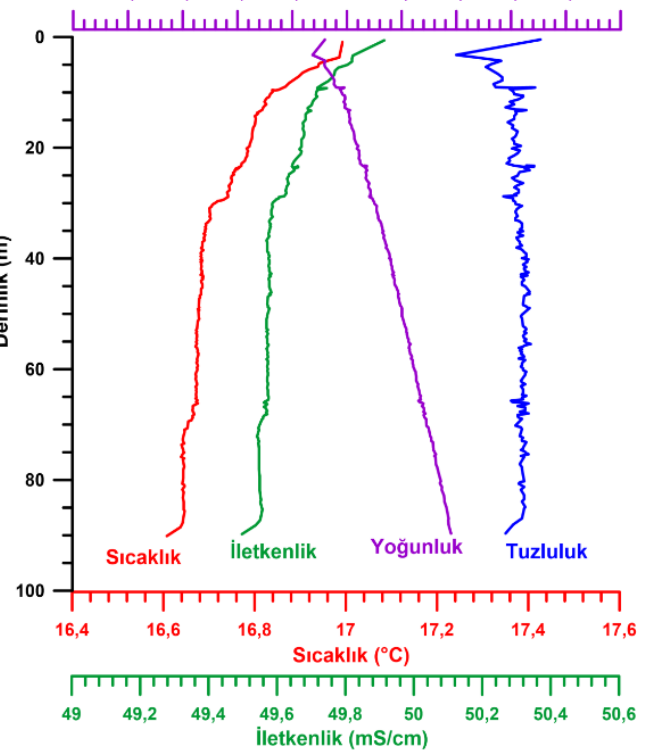

Sığacık Körfezi

İst. C2 - CTD

Tuzluluk (ppt)

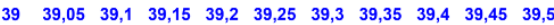

لسلسلسلسلسلسلسلسلسلسلسسا

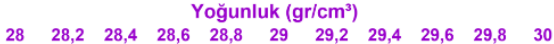

\section{Sığacık Körfezi}

Ist. C3 - CTD Tuzluluk (ppt)

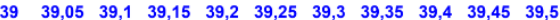

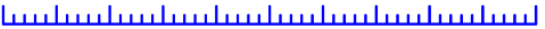

Yoğunluk (gr/cm $\left.{ }^{3}\right)$

$\begin{array}{lllllllllll}28 & 28,2 & 28,4 & 28,6 & 28,8 & 29 & 29,2 & 29,4 & 29,6 & 29,8 & 30\end{array}$

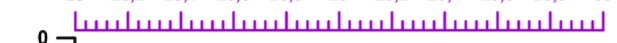

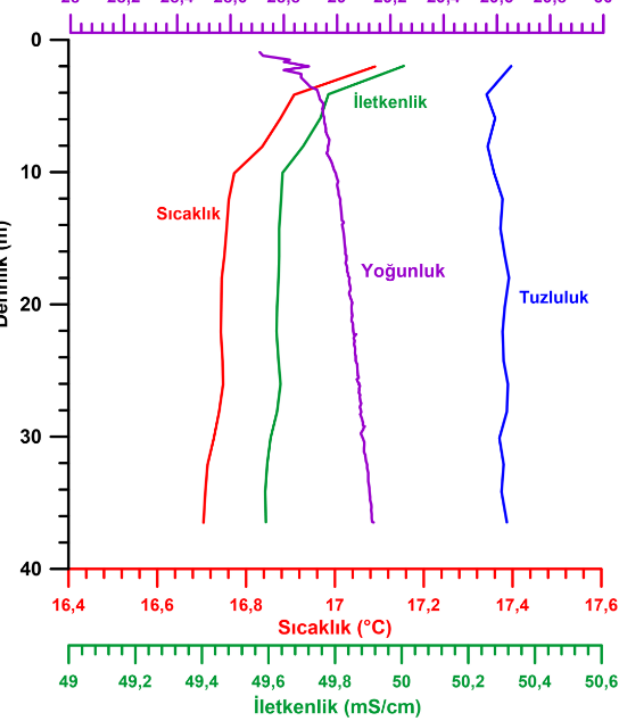

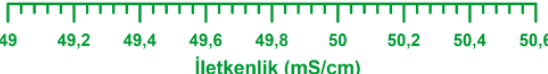

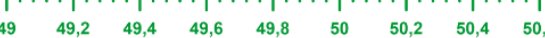
İletkenlik $(\mathrm{mS} / \mathrm{cm})$

Şekil 2. Nisan 2017 - CTD cihazı ile C1, C2 ve C3 istasyonlarında ölçülen sıcaklık $\left({ }^{\circ} \mathrm{C}\right)$, tuzluluk (ppt), iletkenlik $(\mathrm{mS} / \mathrm{cm})$ ve yoğunluk $\left(\mathrm{gr} / \mathrm{cm}^{3}\right)$ değerlerinin deniz yüzeyinden tabanına doğru olan değişimi 
DEU FMD 21(63), 993-1003, 2019



\section{Sığacık Körfezi}

ist. C4 - CTD

Tuzluluk (ppt)

$\begin{array}{lllllllllll}39 & 39,05 & 39,1 & 39,15 & 39,2 & 39,25 & 39,3 & 39,35 & 39,4 & 39,45 & 39,5\end{array}$

لسلسلسيسلسلسلسلسلسلسلسلسا Yoğunluk (gr/cm³)

$\begin{array}{lllllllllll}28 & 28,2 & 28,4 & 28,6 & 28,8 & 29 & 29,2 & 29,4 & 29,6 & 29,8 & 30\end{array}$

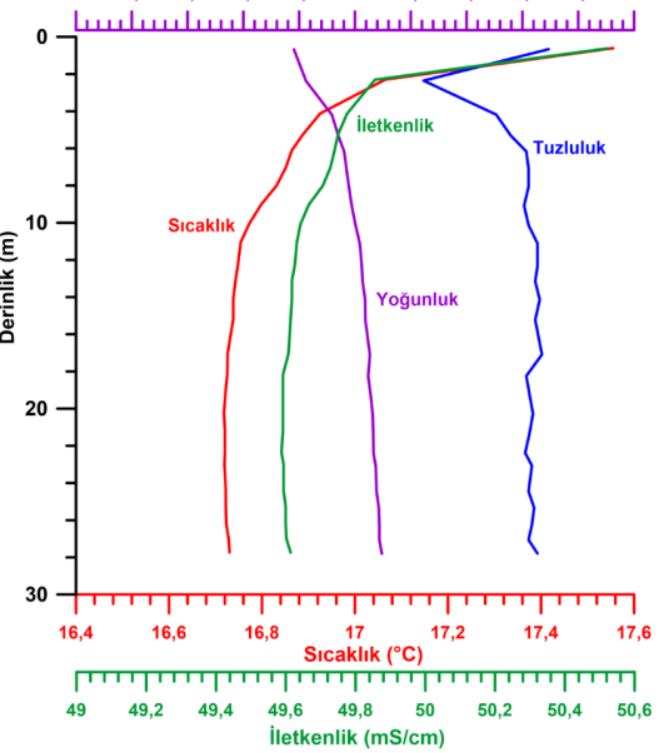

Sığacık Körfezi

İst. C5 - CTD Tuzluluk (ppt)

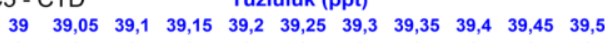

لسلسلسيسلسلسلسلسلسلسلسار Yoğunluk ( $\left(\mathrm{gr} / \mathrm{cm}^{3}\right)$

Sığacık Körfezi
İst. C6 - CTD


لسلسلسلسلسلسلسلسلسلسلسر

$\begin{array}{lllllllllll}28 & 28,2 & 28,4 & 28,6 & 28,8 & 29 & 29,2 & 29,4 & 29,6 & 29,8 & 30\end{array}$
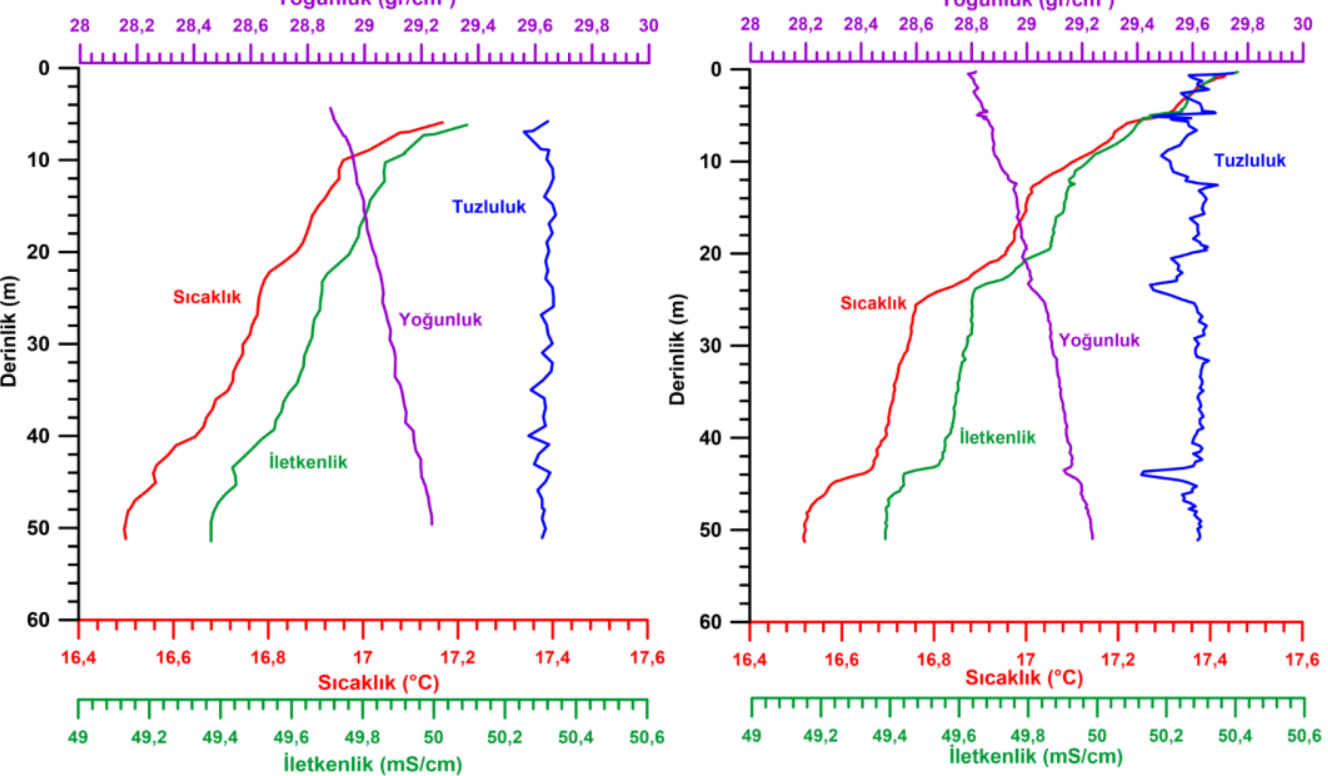

Şekil 3. Nisan 2017 - CTD cihazı ile C4, C5 ve C6 istasyonlarında ölçülen sıcaklık $\left({ }^{\circ} \mathrm{C}\right)$, tuzluluk (ppt), iletkenlik $(\mathrm{mS} / \mathrm{cm})$ ve yoğunluk $\left(\mathrm{gr} / \mathrm{cm}^{3}\right)$ değerlerinin deniz yüzeyinden tabanına doğru olan değișimi 

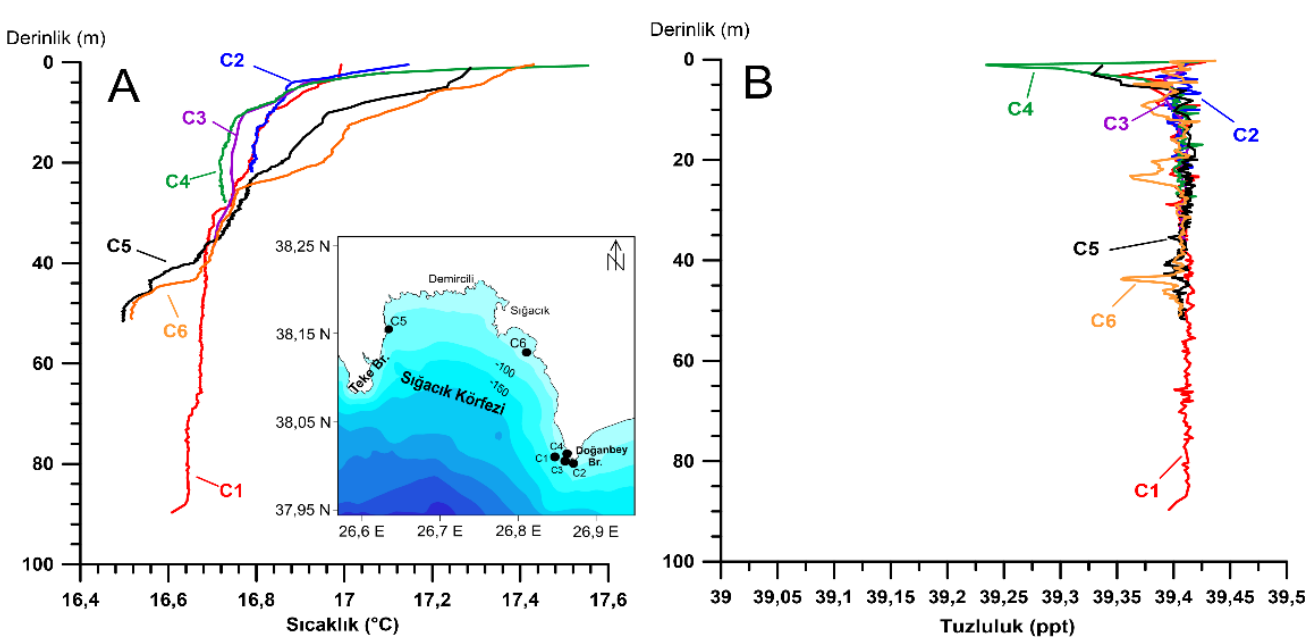

Şekil 4. Nisan 2017 CTD cihazı ile ölçülen a) sıcaklık ve b) tuzluluk verilerinin istasyonlara göre değișimi.

Çalışma alanında As konsantrasyonu $<0,01 \mathrm{mg} / \mathrm{L}$ ölçülmüștür. Çalışmada alınan su örneklerindeki $\mathrm{Ca}^{+}, \mathrm{Mg}^{+2}, \mathrm{Na}^{+2}, \mathrm{~K}^{+}, \mathrm{Li}^{+}, \mathrm{As}, \mathrm{B}^{+}, \mathrm{Cl}^{-}, \mathrm{SO}_{4}^{-2}, \mathrm{SiO}_{2}$ ve $\mathrm{HCO}_{3}^{-}$konsantrasyon miktarlarında hidrotermal kaynakların etkisine rastlanamamıștır. Nisan 2017 CTD verileri kullanılarak su kolonu sıcaklık, tuzluluk, iletkenlik ve yoğunluk değișimleri değerlendirilmiștir. Buna göre; C1 istasyonunda deniz yüzeyinde sıcaklık $16,99^{\circ} \mathrm{C}$ olup $10 \mathrm{~m}, 30 \mathrm{~m}$ ve $70 \mathrm{~m}$ derinliklerde sirası ile sicaklıklar; $16,83^{\circ} \mathrm{C}, 16,70^{\circ} \mathrm{C}$ ve $16,65^{\circ} \mathrm{C}$ 'dir (Şekil 2). Dip su ( $87 \mathrm{~m}$ derinlikte) sıcaklığı ise $16,64^{\circ} \mathrm{C}$ ölçülmüștür. Yüzey ve deniz tabanı arasındaki sıcaklık farkı $0,35^{\circ} \mathrm{C}$ olup Sekil 2'deki sıcaklık profilinde $10 \mathrm{~m}, 30 \mathrm{~m}$ ve $70 \mathrm{~m}$ derinlikte üç farklı su tabakası gözlenmiștir. Sıcaklık profilinde deniz tabanına doğru $30 \mathrm{~m}$ ve $70 \mathrm{~m}$ derinliklerde sıcaklık değerinin yaklașık $0,04^{\circ} \mathrm{C}$ azaldığı gözlenmiştir. Öte yandan C1 sıcaklık profilini, C5 ve C6 istasyonları ile karșılaștırdığımızda 51m derinliğe kadar C1 istasyonundaki sıcaklığın daha yüksek olduğu gözlenmiştir. Bu durum istasyondaki sıcaklık değerlerinin deniz tabanındaki hidrotermal kaynakların etkisi olabileceği şeklinde yorumlanmıștır. İletkenlik değerleri, yüzeyde $49,91 \mathrm{mS} / \mathrm{cm}$ iken deniz tabanında $(87 \mathrm{~m}$ derinlikte) $49,55 \mathrm{mS} / \mathrm{cm}^{\prime}$ dir. İletkenlik profili,

sıcaklık profiline paralel olarak yüzeyden deniz tabanına doğru değişim göstermiş olup termoklinin etkisi ile birlikte üç farklı su tabakası gözlenmiştir. Tuzluluk değerleri yüzeyde 39,428 ppt iken deniz tabanında $(87 \mathrm{~m}$ derinlikte) 39,411 ppt'dir. Yüzey ve dip sudaki tuzluluk değerleri arasında 0,017 ppt azalma gözlenmiștir. Yoğunluk değerleri ise deniz yüzeyinden $28,92 \mathrm{gm} / \mathrm{cm}^{3}$ deniz tabanına (87 m derinlikte) $29,37 \mathrm{gr} / \mathrm{cm}^{3}$ ölçülmüştür.

C2 istasyonunda deniz yüzeyinde sicaklık $17,14^{\circ} \mathrm{C}$ olup $10 \mathrm{~m}, 20 \mathrm{~m}$ ve deniz tabanında $\left(21,8 \mathrm{~m}\right.$ derinlikte) sirasiyla $16,88^{\circ} \mathrm{C}, 16,79^{\circ} \mathrm{C}$ ve $16,79^{\circ} \mathrm{C}^{\prime}$ dir (Şekil 2). Deniz tabanına doğru sıcaklığın azalması beklenirken, 21,8m derinlikte sicaklık $16,786^{\circ} \mathrm{C}, 21,35 \mathrm{~m}$ derinlikte $16,787^{\circ} \mathrm{C}$ ye ve dip su sıcaklığı $16,791^{\circ} \mathrm{C}$ değerine ulaşmıştır. Bununla birlikte yüzey ve dip su arasındaki sıcaklık farkı $0,35^{\circ} \mathrm{C}$ olup yüzey sıcaklık değerleri yaklașık ilk $5 \mathrm{~m}$ derinlikte daha keskin değișimin gözlendiği termoklin derinliği olarak belirlenmiştir. Yüzeydeki bu durum ölçümlerin alındığı ilkbahar mevsiminde atmosferik etkinin olduğu ve yüzeyde tabakalaşmanın başladığı șeklinde yorumlanmıștır. İletkenlik deniz yüzeyinde $50,06 \mathrm{mS} / \mathrm{cm}$ olup $10 \mathrm{~m}, 20 \mathrm{~m}$ derinlikte $49,70 \mathrm{mS} / \mathrm{cm}$ ve $49,67 \mathrm{mS} / \mathrm{cm}$ ölçülmüștür. İletkenlik profilinde de deniz tabanına doğru azalım gözlenirken deniz tabanına çok yakın $21 \mathrm{~m}$ ve $21,5 \mathrm{~m}$ derinliklerde iletkenlik değerlerinde önemli değişimler dikkatimizi çekmiştir. 
DEU FMD 21(63), 993-1003, 2019

Tablo 1. Su örneklerinin kimyasal analiz sonuçları konsantrasyon miktarları (mg/L)

\begin{tabular}{|c|c|c|c|c|c|c|c|c|c|c|c|}
\hline İstasyon & Enlem & Boylam & Derinlik (m) & $\mathrm{Ca}^{+2}$ & $\mathbf{M g}^{+2}$ & $\mathrm{Na}^{+2}$ & $\mathrm{~K}^{+}$ & $\mathbf{L i}^{+}$ & $\mathrm{Cl}^{-}$ & $\mathrm{SO}_{4}^{-2}$ & $\mathrm{HCO}_{3}^{-}$ \\
\hline K1 & 38.0337 & 26.8507 & 84 & 486 & 1464 & 12249 & 596 & 0,13 & 23993 & 3088 & 154 \\
\hline K2 & 38.0588 & 26.8493 & 70 & 478 & 1424 & 11360 & 667 & 0,08 & 22493 & 3177 & 178 \\
\hline K3 & 38.1413 & 26.8037 & 63 & 492 & 1462 & 11450 & 463 & 0,07 & 22743 & 3217 & 173 \\
\hline K4 & 38.1780 & 26.6307 & 43 & 438 & 1585 & 13087 & 536 & 0,1 & 22493 & 3078 & 171 \\
\hline K5* & 38.1072 & 26.6149 & 95 & 482 & 1514 & 11540 & 447 & 0,09 & 22743 & 3277 & 173 \\
\hline
\end{tabular}

$\mathrm{Bu}$ derinliklerde iletkenlik değerleri sırasıyla 49,674 mS/cm ve 49,682 mS/cm ölçülmüș ve bu değer dip suda 49,68 mS/cm'dir. Benzer durum tuzluluk değerlerinde de gözlenmiștir.

Yüzeyde 39,413 ppt iken, belirtilen derinliklerde sirasiyla 39,406 ppt $(21 \mathrm{~m})$ ve 39,416 ppt $(21,5)$ ölçülmüş ve bu değer deniz tabanına doğru azalarak deniz tabanında $(21,8 \mathrm{~m}$ derinlikte $)$ 39,412 ppt ölçülmüștür. Yoğunluk deniz yüzeyinde $28,87 \mathrm{gr} / \mathrm{cm}^{3}$ iken deniz tabanına kadar bu değer artarak dip suda $(21,8 \mathrm{~m}$ derinlikte) 29,05 gr $/ \mathrm{cm}^{3}$ ölçülmüștür. Yoğunluk değerlerinde de deniz tabanına yakın $21,07 \mathrm{~m}$ ve $29,35 \mathrm{~m}$ derinlikte sirasiyla $29,044 \mathrm{gr} / \mathrm{cm}$ ve 29,054 olup bu değer deniz tabanına doğru azalarak 29,052 gr/cm ölçülmüştür. C2 istasyonunda özellikle dip su sicaklık değerlerinin deniz tabanına yakın derinliklerde azalmaması ve hatta dikey yönde (sabit sıcaklık) değişim göstermesi bölgede hidrotermal kaynakların etkisini göstermektedir.

C3 istasyonunda deniz yüzeyinde sıcaklık $17,09^{\circ} \mathrm{C}$ olup $10 \mathrm{~m}, 20 \mathrm{~m}, 30 \mathrm{~m}$ ve dip su $(36,5 \mathrm{~m}$ derinlik) sicaklıkları ise sirasıyla $16,77^{\circ} \mathrm{C}$, $16,74^{\circ} \mathrm{C}, 16,72^{\circ} \mathrm{C}$ ve $16,70^{\circ} \mathrm{C}^{\prime}$ dir (SSekil 2). Deniz yüzeyi ve tabanı arasındaki sıcaklık farkı $0,60^{\circ} \mathrm{C}$ 'dir. Termoklin seviyesi $8 \mathrm{~m}$ ve $32 \mathrm{~m}$ derinliklerde belirlenmiştir. Yüzey sıcaklık değerleri ( $\mathrm{C} 2$ istasyonuna benzer) yaklaşık ilk 10 $m$ derinlik içerisinde ani bir azalım $\left(-0,52^{\circ} \mathrm{C}\right)$ pgözlenmiștir. Bu durumun aynı șekilde ilkbahar mevsiminde sıcaklığın etkili olduğu ve yüzeyde tabakalaşmanın başladığı şeklinde yorumlanmıștır. İletkenlik deniz yüzeyinde $50,06 \mathrm{mS} / \mathrm{cm}$ olup sicaklık profiline paralel biçimde devam ederek deniz tabanında $(36,5 \mathrm{~m}$ derinlikte) 49,59 mS/cm ölçülmüștür. Tuzluluk ve yoğunluk deniz yüzeyinde sırasıyla 39,415 ppt ve $28,89 \mathrm{gr} / \mathrm{cm}^{3}$ iken deniz tabanında bu değerler 39,411 ppt ve 29,137 $\mathrm{gr} / \mathrm{cm}^{3}$ ölçülmüștür.

C4 istasyonunda deniz yüzeyinde sıcaklık, iletkenlik, tuzluluk ve yoğunluk değerleri $17,55^{\circ} \mathrm{C}, 50,52 \mathrm{mS} / \mathrm{cm}, 39,42$ ppt ve 28,77 $\mathrm{gr} / \mathrm{cm}^{3}$ ölçülmüştür (Şekil 3). $10 \mathrm{~m}$ ve $20 \mathrm{~m}$ derinliklerde sicaklık $16,77^{\circ} \mathrm{C}-16,71{ }^{\circ} \mathrm{C}$, iletkenlik 49,64 - 49,59 mS/cm, tuzluluk 39,40 39,41 ppt ve yoğunluk $29,00-29,06 \mathrm{gr} / \mathrm{cm}^{3}$ ölçülmüş olup deniz tabanında $(27,8 \mathrm{~m}$ derinlikte) bu değerler; $16,72^{\circ} \mathrm{C}, 49,61 \mathrm{mS} / \mathrm{cm}$, $39,410 \mathrm{ppt}$ ve $29,09 \mathrm{gr} / \mathrm{cm}$ ölçülmüştür. Yüzey ile deniz tabanındaki sıcaklık farkı $0,825^{\circ} \mathrm{C}$, termoklin seviyesi $8 \mathrm{~m}$ olarak belirlenmiștir. Buna göre termoklin seviyesinin C2 ve C3 istasyonu ile uyumlu olduğu gözlenmiștir. Yüzey sıcaklık değerleri C2 ve C3 istasyonlarında olduğu gibi yaklaşık ilk $8 \mathrm{~m}$ derinlikte daha hızlı bir azalım $\left(0,65^{\circ} \mathrm{C}\right)$ gözlenmiștir. Benzer șeklide bu istasyonda da yüzeyde tabakalaşmanın başladığı görülmüştür. Sıcaklık değişiminin etkisi tuzluluk profilinde de gözlenmiștir. C4 istasyonunda, C2 istasyonundaki gibi deniz tabanında önemli değişimler burada da dikkatimizi çekmiștir. Deniz tabanına doğru 25 m derinlikte sıcaklık $16,704^{\circ} \mathrm{C}$, iletkenlik 49,588 $\mathrm{mS} / \mathrm{cm}$, tuzluluk 39,406 ppt ve yoğunluk 29,128 $\mathrm{gr} / \mathrm{cm}^{3}$ iken, $25 \mathrm{~m}$ derinlikte sicaklık $16,706^{\circ} \mathrm{C}$, iletkenlik $49,618 \mathrm{mS} / \mathrm{cm}$, tuzluluk 39,410 ppt ve yoğunluk 29,094 $\mathrm{gr} / \mathrm{cm}^{3}$ ölçülmüştür. Deniz tabanına doğru sıcaklık profilindeki bu artış bölgedeki deniz içi hidrotermal çıkışların etkisinden kaynaklandığı şeklinde yorumlanmıștır.

C5 istasyonunda deniz yüzeyinde sıcaklık, iletkenlik, tuzluluk ve yoğunluk değerleri sirasiyla $17,16^{\circ} \mathrm{C}, 49,95 \mathrm{mS} / \mathrm{cm}, 39,414$ ppt ve $28,931 \mathrm{gr} / \mathrm{cm}^{3}$ iken, $20 \mathrm{~m}$ derinlikte $16,86^{\circ} \mathrm{C}$, $49,75 \mathrm{mS} / \mathrm{cm}, 39,41 \mathrm{ppt}$ ve $29,02 \mathrm{gr} / \mathrm{cm}^{3}, 40 \mathrm{~m}$ derinlikte ise $16,64^{\circ} \mathrm{C}, 49,51 \mathrm{mS} / \mathrm{cm}, 39,39 \mathrm{ppt}$ 


\section{DEU FMD 21(63), 993-1003, 2019}

ve $29,15 \mathrm{gr} / \mathrm{cm}^{3}$ ölçülmüștür (Șekil 3). Deniz tabanında $(51 \mathrm{~m}$ derinlikte $)$ ise belirtilen parametreler $16,50^{\circ} \mathrm{C}, 49,37 \mathrm{mS} / \mathrm{cm}, 39,40 \mathrm{ppt}$ ve $29,24 \mathrm{gr} / \mathrm{cm}^{3}$ ölçülmüştür. CTD profillerinde, $10 \mathrm{~m}, 22,5 \mathrm{~m}$ ve $40 \mathrm{~m}$ derinlikte üç üç farklı su tabakası gözlenmiștir. Bunlar körfez içerisinde meydana gelen akıntıların etkisi olarak yorumlanmıştır. Sıcaklık profilindeki değișim, iletkenlik profilinde de net bir şekilde gözlenmiştir.

C6 istasyonunda deniz yüzeyinde sıcaklık $17,43^{\circ} \mathrm{C}$, iletkenlik $50,40 \mathrm{mS} / \mathrm{cm}$, tuzluluk $39,437 \mathrm{ppt}$ ve yoğunluk $28,81 \mathrm{gr} / \mathrm{cm}^{3}$ iken bu değerler $20 \mathrm{~m}$ derinlikte $16,94^{\circ} \mathrm{C}, 49,83 \mathrm{mS} / \mathrm{cm}$, $39,39 \mathrm{ppt}$ ve $28,09 \mathrm{gr} / \mathrm{cm}^{3}$ ve $40 \mathrm{~m}$ derinlikte $16,68^{\circ} \mathrm{C}, 49,56 \mathrm{mS} / \mathrm{cm}, 39,40$ ppt ve 29,15 $\mathrm{gr} / \mathrm{cm}^{3}$ ölçülmüştür (Şekil 3). Deniz tabanında (51 m derinlikte) ise bu değerler $16,51^{\circ} \mathrm{C}, 49,38$ $\mathrm{mS} / \mathrm{cm}, 39,405 \mathrm{ppt}$ ve $29,41 \mathrm{gr} / \mathrm{cm}^{3}$ 'dür. Yüzey ve deniz tabanı arasındaki sıcaklık farkı $0,91^{\circ} \mathrm{C}$ olup termoklin seviyesi C5 istasyonunda olduğu gibi $12 \mathrm{~m}, 24 \mathrm{~m}$ ve $44 \mathrm{~m}$ derinliklerde üç farklı su tabakası gözlenmiştir.

İstasyonlara ait sıcaklık ve tuzluluk değerleri tek bir grafik üzerinde incelendiğinde (Șekil 4); Doğanbey Burnu açılarında bulunan C1 istasyonu ile C5 ve C6 istasyonları karşılaştırıldığında ilk 50m derinlikteki sıcaklık değerinin yüksek olduğu görülmüștür. $\mathrm{Bu}$ durum, C1 istasyonunun kıyıya yakın deniz içi sıcak hidrotermal kaynakların etkisi altında olabileceği şeklinde yorumlanmıștır. Doğanbey Burnuna yakın C2, C3 ve C4 istasyonlarınında benzer șekilde C5 ve C6 istasyonlarına göre taban sıcaklıklarının daha yüksek olduğu gözlenmiştir. Sığacık Körfezi kıyı bölgesinde yer alan C5 ve C6 istasyonlarında ise termal etki gözlenmemiş olup sıcaklık profilinde üç farklı su tabakası belirlenmiștir (Şekil 3 ve 4). Bu durumun körfez genelinde de gözlemlenebileceği düşünülmektedir. Belirtilen üç farklı su tabakası yüzeyden itibaren; 0,0 - 10,0 m (yüzey suları), 10 - 24 m (ara tabaka) ve 24 $44 \mathrm{~m}$ (dip su tabakası) șeklindedir. Şekil 4'de tüm istasyonlardaki tuzluluk profillerine göre hidrotermal etkiden bahsetmek doğru olmayacaktır ancak sıcaklık ve iletkenlik parametrelerinde hidrotermal etki net bir şekilde gözlenmiștir.

Sığacık Körfezi ve Doğanbey Burnu kıyılarında Nisan 2017 yılı CTD verilerine göre Doğanbey Burnu yakınlarında yer alan C1, C2, C3 ve C4 istasyonlarına ait sicaklık profillerinde deniz tabanında hidrotermal kaynakların etkisi gözlenmiștir. Bölgede daha detaylı olarak mevsimsel veya aylık olarak Doğanbey Burnu ve çevresinde su kolonu içerisindeki fiziksel parametrelerin değişimlerinin araştırılması önerilmektedir.

\section{Teşekkür}

Çalışma yazarlardan Özde BAKAK'ın doktora tez çalıșmasının bir bölümünü olușturmakta olup Dokuz Eylül Üniversitesi Bilimsel Araştırma Projesi (BAP) tarafından (2012.KB.FEN.106) nolu proje kapsamında desteklenmiștir. Calıșma kapsamında su kolonu içerisindeki fiziksel parametrelerin ölçülmesinde kullanılan CTD cihazı TUBITAK 115 Y180 projesi kapsamında alınmıs ve projemizde de kullanılmıstır. CTD cihazı ile ölçüm alımı ve verilerin değerlendirilmesinde yardımlarını esirgemeyen Prof. Dr. Muhammet DUMAN ve Prof. Dr. Erdem SAYIN'a tessekkürlerimizi sunarız. Düzenlenen seferlerde gemi kaptanı ve gemi personeline teşekkür ederim. Kimya analizleri için yardımlarından dolayı Dokuz Eylül Üniversitesi Cevre Mühendisliği Atık Su Labratuarı personeline teșekkür ederiz. Makalemizin son halini almamızda çok büyük katkı sağlayan editör ve hakemlere teșekkürü bir borç biliriz.

\section{Kaynakça}

[1] Meriç, E., Barut, İ.P., Nazik, A., Avşar, N., Yokeş, M.B., Eryılmaz, M., Yücesoy-Eryılmaz, F., Kam, E., Sonuvar, B., Dinçer, F. 2018. Doğanbey Burnu (Seferihisar-İzmir) denizdibi termalsu kaynaklarının foraminifer, ostrakod ve mollusk topluluğuna etkisi. Maden Tetkik ve Arama Dergisi, 156: 89-118, DOI: 10.19706/mta.363316.

[2] Meriç, E., Avşar, N., 2001. Benthic foraminiferal fauna of Gökçeada Island (Northern Aegean Sea) and its local variations. Acta Adriatica, 42 (1), 125150.

[3] Meriç, E., Avşar, N., Nazik, A., Koçak, F., YücesoyEryılmaz, F., Eryılmaz, M., Barut, İ. F., Yokes, M. B., Dinçer, F., Esenli, F., Esenli, V., Özdemir, Z., Türker, A., Aydın, Ş., 2012. Edremit Körfezi (Balıkesir) kıyı alanlarında oșinografik özellliklerin bentik foraminifer, ostrakod ve bryozoon toplulukları üzerindeki etkileri ile ilgili yeni veriler. T.P.J.D. Bülteni, 24 (2), 31-77, Ankara. Meriç vd. / Yerbilimleri, 2018, 39 (3), 207-220 217.

[4] Meriç, E., Avşar, N., Nazik, A., Yokeş, B., Barut, İ. F., Suner, F., Sarı, E., Eryılmaz, M., YücesoyEryılmaz, F., Dora. Ö., Kam, E., Dinçer, F., 2017. A multi disciplinary overview of factors controlling on microfauna assemblages around Maden and Alibey islands in Ayvalik (Balikesir, Eastern Aegean Sea). Journal of African Earth Sciences,129, 558-578.

[5] Meriç, E., Avşar, N., Bergin, F., Barut, İ., 2003. Dikili Körfezi'nde (Kuzeydoğu Ege Denizi-Türkiye) bulunan üç anormal bentik foraminifer örneği: Peneroplis planatus (Fichtel ve Moll), Rosalina sp. ve Elphidium crispum (Linne) hakkında. M.T.A. Dergisi, 127, 67-81, Ankara. 


\section{DEU FMD 21(63), 993-1003, 2019}

[6] Meriç, E., Nazik, A., Yokeş, M. B., Barut, İ. F., Kumral M., Eryılmaz, M., Yücesoy-Eryılmaz, M., Sonuvar, B., Dinçer, F., 2018. Aliağa (İzmir) sıcak ve soğuk su çıktıları çevresinde meiobentik yaşam: foraminifer, ostrakod ve mollusk toplulukları.Türkiye Jeoloji Bülteni (yayın aşamasında).

[7] Meriç, E., Avşar, N., Nazik, A., Yokeş, Dora, Ö., Barut, İ. F., Eryılmaz, M., Dinçer, F., Kam, E., Aksu, A., Tașkın, H., Bașsarı, A., Bircan, C., Kaygun, A., 2012. Karaburun Yarımadası kuzey kiyılarının oşinografik özelliklerinin bentik foraminifer ve ostrakod toplulukları üzerindeki etkileri. M.T.A. Dergisi, 145, 22- 47, Ankara.

[8] Çağlar, K. Ö., 1946. Türkiye maden suları ve kaplıcaları. Maden Tetkik ve Arama Enstitüsü yayınları, B, 11, 791 s., Ankara.

[9] Başkan, E., Canik, B., 1983. Türkiye sıcak ve mineralli sular haritası, Ege bölgesi. MTA Enstitüsü yayınları, 189, 80 s., Ankara.

[10] Meriç, E., Barut, İ.F., Yokeș, M.B., Eryılmaz, M., Yücesoy-Eryılmaz, F., Dinçer, F. 2018. Doğu Ege Denizi Türkiye Kyılarında Varlığı Bilinen veya Düşünülen Deniz İçi Termal Çıktılar Çevresinde Gözlenen Bentik Foraminifer Toplululuklarında Belirlenen Değişimler ve Etkenler. Yerbilimleri, (39), 207-220.

[11] Drahor, M.G., Sarı, C., ve Șalk, M. 1999. Self potential and gravity studies in the Seferihisar geothermal field. Dokuz Eylül University Engineering Faculty, Journal of Science and Engineering, 13, 97-112.

[12] Toygar, A.A. 2012. Seferihisar Balçova jeotermal alanlarında ve çevre akiferlerinde akışkan akımının modellenmesi. Dokuz Eylül Üniversitesi, Fen Bilimleri Enstitüsü, Doktora Tezi, 203s, İzmir.

[13] Eryılmaz, M., Yücesoy Eryılmaz, F., Eryılmaz, U., 2016. Doğanbey Koyu'nun (Kuşadası Körfezi) Oșinografisi ve Güncel Cökel Dağılımı. TMMOB Jeoloji Mühendisleri Odası, 69. Türkiye Jeoloji Kurultayı, 11-15 Nisan 2016, s.72-73, Ankara.

[14] Eryılmaz, M. ve Yücesoy Eryılmazi F. 2010. Kuşadası Körfezi'nin oşinografisi güncel sualtı morfolojisi ve çökel dağılımı. SBT 2010, 14. Ulusal Bilim ve Teknoloji Toplantısı, 6-7 Kasım 2010, Bildiriler Kitabı, s. 88-97, Antalya.

[15] Eşder, T. 1988. Gümüldür - Cumaovası (İzmir) alanının jeolojisi ve jeotermal enerji olanaklarının araştırılması. İstanbul Üniversitesi, Doktora Tezi, İstanbul (yayınlanmamış).

[16] Villanueva-Estrada, R.E., Prol-Ledesma, R.M., Rodriguez-Diaz, A.A., Canet, C., 2005. Geochemical Modeling of a Shallow Submarine Hydrothermal System at Bahía Concepción, Proceedings World Geothermal Congress 2005, Antalya, Turkey, 24-29 April 2005.

[17] Meriç, E., Avşar, N., Barut, İ.F., Yokeș, M.B., Taş, S.,Eryılmaz, M., Dinçer, F., Bircan, C. 2009. Kuşadası (Aydın) Deniz Dibi Mineralli Su Kaynağı Çevresi Bentik Foraminifer Topluluğu Hakkında Görüş ve Yorumlar. 13. Sualtı Bilim ve Teknolojisi Toplantısı (SBT 2009) 7-8 Kasım 2009, Lefkoşa/KKTC, 80-92.
[18] Yokeş, M. B., Meriç, E., Avşar, N., Barut, İ. F., Taş, S., Eryılmaz, M., Dinçer, F., Bircan, C., 2014. Opinion and comments on the benthic foraminiferal assemblages observed around the mineral submarine springs in Kuşadası (Aydın-Turkey). Marine Biological Association of the United Kingdom, 1-17, doi:10.1017/ S1755267214000840, vol. 7, e103; 2014, published on line.

[19] German, C.R., ve Von Damm, K.L. 2003. Hydrothermal processes. In: Holland HD, Turekian KK, editors. Treatise on Geochemistry (Volume 6): The Oceans and Marine Geochemistry. Oxford: Elsevier, 181-222.

[20] Ledesma, R.M., Canet, C., Torres-Vera, M.A., Forrest, M.J., Armienta, M.A. 2004. Vent fluid chemistry in Bahia Concepcion coastal submarine hydrotermal system, Baja California Sur, Mexico. Journal of Volcanology and Geothermal Research, 137, 31328,DOI:10.1016/j.jvolgeores.2004.06.003

[21] Villanueva-Estrada, R.E., Prol-Ledesma, R.M., Rodriguez-Diaz, A.A., Canet, C., ve Armienta, M.A. 2013. Arsenic in hot spot of Bahia Concepcion, Baja California Peninsula, Mexico. Chemistry Geology, 348, 27 - 36, DOI: 10.1016/j.chemgeo.2012.09.008.

[22] Varvanas, S.P., Hallbach, P., Hallbach, M., Panagiotaras, D., Rahders, E., Hubner, A. 1999. Characterization of hydrothermal fields and hydrothermal evolution in the Hellenic Volcanic Arc. International Conference Oceanography of the Eastern Mediterranean and Black Sea, 23-26 February 1999, Athens, Greece, Abstract, 343.

[23] Gemi Trafik, 2018. Ilıca Burnu'ndan Kuşadası'na $1 / 150000$ ölçekli harita. http://www.gemitrafik.com/images/charts/TR01 4-Ilica-Kusadasi.JPG (Erişim tarihi : 11 Haziran 2019). 